\title{
KOSMOLOGI, SAINS, DAN TEKNOLOGI: Pergeseran Paradigmatik dan Implikasinya terhadap Studi Agama
}

\author{
Imam Iqbal \\ UIN Sunan Kalijaga Yogyakarta \\ Imam_iqbal@yahoo.co.id
}

\begin{abstract}
Abstrak
Alam semesta, selain menjadi "subject matter" kosmologi, juga merupakan salah satu koordinat penentu perkembangan paradigma. Peralihan yang terjadi di ranah kosmologi secara sirkuler akan berakibat pada pergeseran paradigma dan pencapaian peradaban. Sirkularitas perkembangan inilah yang ditemukan dalam peradaban manusia. Tulisan ini berupaya menapaki perkembangan itu secara deskriptif-eksploratif. Dari titik ini, ditemukan: pertama, perkembangan sains dan teknologi manusia modern dipengaruhi oleh kosmologi Cartesian-Newtonian; Kedua, meski telah menghasilkan sukses spektakuler, kosmologi modern yang bercorak positivistik itu tetap memiliki cacat internal. Ini terbukti dari hujatanhujatan yang muncul dari wilayah keilmuan yang sama dengan wilayah yang digeluti oleh kosmologi lama, meski muncul dengan asumsi-asumsi yang banyak berseberangan dengan yang lama. Ketiga, implikasi perubahan kosmologi ternyata juga merambah dimensi kehidupan manusia lainnya, terutama agama. Secara langsung, peralihan kosmologi ini menuntut respon agama untuk tidak melulu berpijak pada pola doktriner yang terlalu mengandalkan teks-teks suci,tetapi harus pula mempertimbangkan unsur-unsur lainnya yang selama ini tidak diperhitungkan.
\end{abstract}

Abstract

COSMOLOGY, SCIENCES, AND TECHNOLOGY: SHIFTING OF PARADIGM AND ITS IMPLICATIONS FOR RELIGIOUS STUDIES. The universe, aside from being "subject matter" of cosmology, is also one of the determining coordinates of paradigm development. The transition happening in the realm of cosmology circular will result in a paradigm shift and the achievement of civilization. It is the circularity of this development which is 
found in the human civilization. This paper seeks to tread the development in a descriptive-explorative way. From this point, this study reveals three things: first, the development of science and technology of modern humans is influenced by the Cartesian-Newtonian model of cosmology; Secondly, in spite of its spectacular success, positivistic character of modern cosmology still has an internal defect. Such faulty is evidently demonstrated by blasphemies arising from the same area cultivated by the old cosmology, although they appear with many assumptions at odds with the old one. Third, the implications of changes in cosmology also penetrate other dimensions of human life, especially religion. Such transitions require religion not merely to stand on the doctrinaire attitudes relying on sacred texts, but it should also consider other elements which previously have not been taken into account.

Kata Kunci: sains Islam; filsafat ilmu; epistemologi

\section{A. Pendahuluan}

Secara umum, kosmologi merujuk kepada ilmu tentang alam semesta sebagai sistem yang rasional dan teratur. Kosmologi dibahas pertama kalinya sebagai cabang metafisika yang bergumul dengan perihal asal dan susunan alam raya, penciptaan, kekekalan, vitalisme, mekanisme, kodrat hukum, ruang, waktu, dan kausalitas. Dalam pembahasan yang bercorak metafisik ini, kosmologi hadir sebagai upaya manusia dalam memahami semesta raya dan menentukan posisi di dalamnya. Hal ini didasari oleh adanya keyakinan manusia bahwa di balik gerakan-gerakan planet yang kelihatannya kacau, pasti ada suatu pola nyata yang sesuai dengan hukum yang mengatur mekanisme gerakan tersebut. ${ }^{1}$ Pendasaran inilah yang selanjutnya menghasilkan pandangan kosmologis tertentu yang silih berganti dipahami oleh manusia, sejak dari geosentrisme, hingga heliosentrisme dan relativisme.

Perbedaan pandangan kosmologis manusia sebagaimana yang tampak di atas, menyiratkan bahwa alam semesta sebagai subject matter pembahasan dalam kosmologi merupakan suatu "entitas" misterius yang mengandung sejuta rahasia dan teka-teki. Akan tetapi, justru dari kemisteriusan alam semesta inilah muncul keinginan manusia untuk memahami dan menentukan posisi di dalamnya.

Dalam kaitannya dengan perkembangan peradaban manusia

${ }^{1}$ Lorens Bagus, Kamus Filsafat, (Jakarta: Gramedia, 2000), h. 499-500. 
dewasa ini yang ditandai oleh laju pertumbuhan sains dan teknologi yang semakin pesat, kosmologi memainkan peran yang sangat signifikan. Eksplorasi ilmiah terhadap alam tidak akan mungkin bisa dicapai jika manusia tidak memunculkan semacam hipotesa tentang kemisteriusan semesta raya, sebagaimana disebutkan di atas. Demikian juga, eksplorasi tersebut tidak akan bisa dilakukan jika manusia masih mencampur-adukkan dan tidak mampu memilahmilah unsur-unsur yang terkait dengan keberadaan alam semesta itu. Singkatnya, pandangan manusia terhadap semesta raya, di samping telah menghasilkan pemahaman-pemahaman yang tidak seragam dari generasi ke generasi, juga berimplikasi pada pergeseran cara pandang manusia terhadap segala sesuatu yang terkait dengan kosmologi tersebut, baik yang berada di wilayah natural sciences maupun yang berada di ranah social and humanities.

Melalui makalah ini, penulis hendak melakukan "napak tilas" terhadap perkembangan besar yang telah dicapai, yang terkait dengan persoalan kosmologi ini. Pada tahap pertama, persoalan kosmologi yang terkait erat dengan sains dan teknologi, akan menjadi pusat perhatian utama dalam makalah ini. Agar menjadi lebih fokus, maka pembahasan dalam makalah ini akan dibatasi pada pergeseran paradigmatik yang terjadi di wilayah kosmologi ini, khususnya pasca terjadinya revolusi ilmiah yang spektakuler dalam perkembangan sains dan teknologi. ${ }^{2}$ Untuk menegaskan letak persoalan dan tahap yang mengiringi pusat perhatian utama di atas, maka perlu diajukan beberapa pertanyaan: pertama, bagaimanakah kosmologi modern menggawangi munculnya revolusi ilmiah yang telah memicu pesatnya

${ }^{2}$ Tokoh yang segera terlintas ketika berbicara tentang "paradigma” adalah Thomas S. Kuhn (1922-1996), filosof dan sejarawan sains Amerika yang pada 1962 meluncurkan masterpiece-nya The Structure of Scientific Revolution. Dalam konteks sains, Kuhn menggunakan istilah "paradigma” untuk banyak makna, seperti disciplinary matrix, weltanschaung, world-view, dan model atau pola berpikir kaum ilmuwan. Menurutnya, perubahan paradigma berimplikasi pada perubahan cara-pandang para ilmuwan dalam menyikapi dunia risetnya. Lihat: Thomas S. Kuhn, The Structure of Scientific Revolution, (Chicago: The University of Chicago Press, 1970), h. 107. Untuk penggunaan yang lebih umum, istilah "paradigma" ini merujuk kepada seperangkat asumsi teoritis umum, hukumhukum dan teknik-teknik aplikasi yang dianut secara bersama oleh anggota komunitas ilmiah tertentu. Lihat: T. Mautner, (ed.), Dictionary of Philosophy, (London: Penguin Books, 1996), h. 408. 
sains dan teknologi? Kedua, apakah yang berubah-secara fundamentaldalam kosmologi, setelah mengalami pergeseran paradigmatik menuju kosmologi baru? Ketiga, bagaimanakah tanggapan yang muncul dari kalangan agamawan terhadap pergeseran tersebut?

\section{B. Kosmologi Positivistik: Warisan Cartesian-Newtonian yang "Digugat"}

Para pioneeryang memulai pembicaraan tentang kosmologi ini adalah para filosof Yunani Kuno abad ke-6 dan ke-5 SM (Pra-Sokrates). Sebutlah beberapa nama (Herakleitos 540-480 SM, Parmenides 515450 SM, Demokritos 493-404 SM) yang berspekulasi dalam meneliti konsistensi dan perubahan yang terjadi di alam ini dan mencari unsur-unsur pokoknya melalui pengalaman konkret. Upaya-upaya awal ini disintesiskan oleh Aristoteles (384-322 SM) melalui suatu kombinasi antara penelitian eksperimental dan analisis filosofis tentang alam. Pandangan kosmologi klasik ini terus berkembang selama beratus tahun, dengan mengikut-sertakan sains Ptolemeus (140 SM) yang mengajarkan bahwa bumi itu berupa sebuah bola yang tetap di tengah benda-benda. Inilah inti dari pandangan geosentrik tentang alam (berpusat pada bumi).

Pada abad ke-16 kosmologi menemukan bentuk barunya di tangan Nicolaus Copernicus (1473-1543) yang membawa paham heliosentrik (berpusat pada matahari). Paham ini meyakini bahwa bumi adalah salah satu dari bintang-bintang yang tak terhitung jumlahnya, kecepatan cahaya adalah lebih kurang 300.000 km/detik, dan seterusnya. Beberapa temuan lain yang mengikuti Copernican Revolution ini terjadi di ranah fisika, matematika, hingga filsafat. Johannes Kepler (1571-1630) menemukan dua hukum matematis tentang lintasan planet di sekitar matahari, Galileo (1564-1642) menemukan rumusan matematis lintasan peluru di muka bumi, dan Newton (1642-1727) berhasil menurunkan rumus matematis empiris itu secara deduktif dari aksioma-aksioma tentang gerak (yang kemudian dikenal sebagai hukum Newton), dan sebuah hipotesis gaya gravitasi (yang kemudian disebut teori gravitasi Newton). ${ }^{3}$ Tepatnya, jika Kepler berhasil menunjukkan lintasan gerak planet yang

${ }^{3}$ Microsoft.Co., Microsoft Encarta Reference Library Premium \& Encyclopedia Deluxe 2005. 
berbentuk elips dan Galileo sukses menggambarkan gerak parabola peluru di bumi, maka Newton menegaskan bahwa bentuk gerakan itu merupakan konsekuensi matematis dari sifat umum gravitasi dan hukum-hukum geraknya. Dengan sendirinya, temuan-temuan itu menunjukkan adanya keselarasan, dan ketidak-terbelahan antara hukum fisika alam langit dan alam bumi.

Sukses Newton dan kawan-kawan ini juga dipertegas oleh landasan epistemologis dan matematisyang diberikan oleh Descartes. ${ }^{4}$ Dalam hal ini, Descartes mengajarkan kita untuk "menyangsikan segala sesuatu secara metodis”. Baginya, eksistensi segala sesuatu harus diragukan, kecuali kesadaran akan keraguan itu sendiri. Dan dikarenakan keraguan itu menunjukkan aktivitas berpikir, maka ketika kita meragukan sesuatu, berarti saat itu rasio tengah membuktikan eksistensinya. ${ }^{5}$ Pola inilah yang menggambarkan tendensi ego subjektivisme-rasionalitas Cartesian.

Melalui metode keragu-raguan yang diterapkannya ini, Descartes ingin memperoleh pengetahuan yang pasti, sebagaimana yang ia impikan. Berkaca dari prinsip kepastian (certainty) yang dimiliki oleh matematika, Descartes memandang alam memiliki struktur matematis, sehingga segala fenomena fisik bisa dilihat dalam hubungan matematis yang pasti. Baginya, alam raya tidak lain adalah sebuah mesin raksasa yang bekerja sesuai dengan hukumhukum mekanik, dan segala sesuatu dalam alam dapat diterangkan dalam pengertian tatanan dan gerakan dari bagian-bagiannya.

Landasan filosofis dari Descartes dan sintetis kosmologis yang kreatif dari Newton merupakan pilar utama yang menyangga perkembangan sains dan teknologi sejak dimulainya Renaissance dan Aufklarung, atau sejak awal bergulirnya abad modern. Kolaborasi dua paradigma ini digambarkan oleh D.W. Hamlyn sebagai saling

${ }^{4}$ Rene Descartes (1596-1650) dianggap sebagai Bapak Filsafat Modern yang menggawangi era baru filsafat dan pola-pandang manusia. Jargonnya yang sering dikutip: cogito ergo sum (Aku berpikir maka aku ada), menandai kebebasan rasionalitas manusia dari hal-hal yang "irrasional". Dengan kata lain, jargon ini menegaskan bahwa keber-ada-an atau eksistensi manusia (res extensa) ditentukan oleh pikirannya (res cogitan), dan tidak sebaliknya. Lebih lanjut, lihat: Rene Descartes, Discourse on Mehtod, trans. John Veitch, (London: J.M. Dent \& Sons Ltd., 1960).

${ }^{5}$ Ibid., h. 165. 
melengkapi. Artinya, pengaruh sains terhadap filsafat tidak bisa dipandang remeh, dan juga merupakan kesalahan fatal untuk mengganggap kecil pengaruh filsafat Cartesian terhadap perkembangan sains, teknologi dan dunia intelektual kontemporer. ${ }^{6}$

Akan tetapi, pengadopsian warisan Cartesian-Newtonian (yang menggabungkan metode hipotetik-deduktif yang rasionalspekulatif dengan metode eksperimental-induktif yang empirisobjektif) oleh cabang-cabang sains lainnya, turut pula membawa "bias-bias" dari asumsi-asumsi paradigmatik yang dikandungnya. Bias-bias inilah yang banyak digugat pada masa kontemporer, tidak hanya oleh kalangan intelektual dan ilmuwan dan saja, namun juga oleh para filosof dan agamawan. Untuk bisa menemukan bias-bias tersebut, berikut penulis gambaran secukupnya tentang asumsiasumsi paradigmatik Cartesian-Newtonian itu.

Pertama, subjektivisme-antroposentristik. Asumsi ini menempatkan manusia sebagai subjek yang aktif dalam kosmos, yang ditandai oleh aktifitas berpikirnya. Jika diruntut dari sejarahnya, filsafat Cartesian merupakan bentuk pemberontakan terhadap dominasi teologi (agama) terhadap kebebasan berpikir manusia. Maka, ketika manusia berhasil mewujudkan kebebasan itu, alam raya dianggap sebagai second creation yang berada di bawah derajat manusia, sehingga layak untuk dikontrol dan didominasi secara luas. Mungkin bias ini pada awalnya tidak disadari oleh Descartes. Akan tetapi setelah berkembangnya sains dan teknologi, dominasi dan kontrol terhadap alam semakin meluas dan mengkristalkan kesombongan manusia di hadapannya. ${ }^{7}$

Eksistensialitas yang terpusatkan pada ego-subjektivisme ini sekaligus menandakan peralihan filsafat dari "kekaguman terhadap kenyataan" kepada "kekaguman terhadap pengetahuan akan kekaguman" itu sendiri. Bentuk apresiatif dari pengetahuan dan pertanyaan manusia tentangnya dikembalikan pada subjek manusia sendiri. Hal itu tergambarkan dari kecenderungan skeptisisme Cartesian, yang berusaha untuk mengetahui tentang "bagaimana

${ }^{6}$ D.W. Hamlyn, The Penguin History of Western Philosophy, (London: Penguin Books, 1987), h. 144-145.

${ }^{7}$ Huston Smith, Forgotten Truth: The Common Vision of the World's Religions, (New York: HarperCollins, 1992), h. 10. 
saya tahu bahwa saya dapat tahu". Res Cogitan murni bertolak dari kesadaran subjektif yang bersumber dari rasio manusia. ${ }^{8}$

Kedua, dualisme. Bias dualistik dari paradigma Cartesian ini berakar pada pembedaannya yang tegas antara res cogitan dan res extensa; antara subjek dan objek. Meskipun dalam wilayah sains murni pemilahan ini mau tidak mau harus diterapkan dalam suatu penelitian ilmiah, akan tetapi pola yang sama juga diadopsi pada wilayah sosial dan humanitas, sehingga relasi intersubjektif yang semestinya berlaku, justru beralih ke pola relasi subjek-objek. Hal ini semakin memperkuat asumsi subjektivisme-antroposentristik yang melanggengkan dominasi dan kontrol manusia, bukan hanya terhadap semesta raya, namun juga terhadap manusia. Werner Heisenberg (1901-1976), tokoh mekanika kuantum menilai bahwa pemisahan dan dikotomi subjek-objek ini telah jauh menembus pikiran manusia selama tiga abad pasca Descartes. Diperlukan waktu yang sangat lama untuk menggantikannya dengan sikap yang benarbenar berbeda terhadap persoalan realitas. ${ }^{9}$

Ketiga, mekanistik-deterministik. Hal ini berdasarkan asumsi Descartes dan Newton bahwa alam raya merupakan mesin raksasa yang bersifat mekanik. Segala bentuk fenomena alam akhirnya dijelaskan secara linier menurut hukum yang berlaku secara pasti dan deterministik. Dalam ranah biologi, teori Darwin (18091882) tentang evolusi merupakan contoh yang representatif untuk menggambarkan asumsi ini. Hal yang sama juga diterapkan August Comte (1798-1857) dalam menerangkan tahap-tahap sejarah manusia secara sosiologis.

Keempat, reduksionisme-atomistik. Selaras dengan asumsi yang linier, mekanistik, certainty, dan deterministik itu, paradigma Cartesian-Newtonian ini tidak mampu melihat fenomena alam secara menyeluruh, akan tetapi hanya parsial dan atomistik. Dari perspektif kontemporer, paradigma ini dianggap telah "berdosa" karena mereduksi realitas dan fenomena kosmis menjadi bagian yang terpotong-potong. Kekayaan makna yang dikandungnya

${ }^{8}$ Protasius Hardono Hadi, Epistemologi: Filsafat Pengetahuan, (Yogyakarta: Kanisius, 1994), h. 16.

${ }^{9} \mathrm{~W}$. Heisenberg, Physics and Philosophy, (New York: Harper \& Row, 1958), h. 58 . 
menjadi terenggut, dan kesadaran yang dihasilkan darinya menjadi tidak utuh.

Kelima, instrumentalisme. Asumsi ini didasarkan atas modus sains modern yang mengukur kebenaran sains dari sejauh mana ia dapatdigunakan untukmemenuhikepentingan-kepentingan material dan praktis. Ia menjadi terkait erat dengan teknologi, dan menjadikan manusia semakin mendominasi dan mengeksploitasi alam. Mazhab Frankfurt dengan Jurgen Habermas sebagai juru bicaranya, secara terang-terangan menggugat rasionalitas instrumental yang menjadi bias warisan Cartesian-Newtonian ini. ${ }^{10}$

Keenam, materialisme-saintisme. Asumsi ini mengakar dari tidak diakuinya wilayah yang immaterial dan metafisik. Para agamawan paling getol dalam menggugat asumsi ini, karena telah menggoyang paham tentang penciptaan dan pemeliharaan alam oleh Yang Maha Kuasa. Dengan demikian, asumsi ini berpotensi untuk menyingkirkan asumsi teologis yang dianut oleh kalangan agamawan. ${ }^{11}$

Seiring dengan dominasi paradigma Cartesian-Newtonian ini di wilayah sains dan teknologi, bias-bias yang dikandungnyapun ikut menyusup dan menghantui ranah-ranah lain dari kehidupan manusia, sejak dari ranah sosial, politik, ekonomi, pendidikan, budaya, hingga agama. Meskipun paradigma ini banyak menghasilkan terobosan-terobosan baru dalam keilmuan sehingga mendukung aktivitas dan kehidupan manusia secara menyeluruh, namun akhirakhir ini ia banyak digugat, terutama oleh aliran postmodernisme dalam filsafat dan oleh pandangan yang muncul dari konsepsi baru tentang kosmologi.

\section{Munculnya Kosmologi Baru}

Pandangan Descartes dan Newton tentang penciptaan kosmos sebenarnya tidak terlalu bertentangan dengan paham kalangan agamawan. Tapi bagi Descartes, Tuhan hanya menempati wilayah instrumental untuk menjamin validitas pengetahuan manusia terhadap realitas eksternal, sementara bagi Newton, setelah

${ }^{10}$ Jurgen Habermas, Knowledge and Human Interest, (Boston: Beacon Press, 1972), h. 76.

${ }^{11}$ Seyyed Hossein Nasr, Religion and the Order of Nature, (Oxford: Oxford University Press, 1996), h. 142. 
menciptakan partikel-partikel benda, kekuatan-kekuatan antar partikel, dan hukum gerak dasar, maka kehadiran Tuhan di dalam kosmos tidak diperlukan lagi, karena semesta raya akan terus bergerak -secara niscaya- laksana mesin yang diatur oleh hukum-hukum deterministik. Pertentangan terbuka dengan kalangan agamawan justru ditemukan setelah berkembangnya bias-bias warisan CartesianNewtonian ini di berbagai ranah kehidupan manusia. Dan dalam beberapa hal, kalangan agamawan -sadar atau tidak sadar- justru banyak mengadopsi warisan ini guna menopang eksistensi agama dan religiusitas mereka.

Bias-bias inilah yang banyak digugat melalui perkembangan sains dan teknologi yang spektakuler selama kurun waktu tiga abad terakhir. Sejarah mencatat bahwa perkembangan sains modern sangat progresif dan produktif dalam menghasilkan temuan-temuan ilmiah, yang banyak di antaranya telah diterapkan dalam dunia praktis. Istilah-istilah seperti bom atom, industri maju, kapitalisme, globalisasi, neo-liberalisme, bayi tabung, kloning, rontgen, rekayasa genetika, hibrida, komputer, multi-media, internet, dan seterusnya, merupakan term-term introduksi bagi pemikiran dan sains modern.

Terkait dengan kosmologi, penemuan-penemuan baru dapat ditemukan dalam perkembangan fisika, matematika dan biologi. Selama tiga abad terakhir ini, tiga sains tersebut semakin menancapkan kukunya dalam kehidupan manusia, dan bahkan tidak jarang mempertanyakan ulang fondasi sains modern itu sendiri. Di sini bisa disebutkan beberapa pandangan baru, seperti teori relativitas (Albert Einstein), mekanika kuantum dan prinsip ketidak-pastian dan komplementer (hasil deklarasi dari Interpretasi Kopenhagen, terutama Max Born, Heisenberg dan Niels Bohr), ${ }_{12}^{2}$ fisika bootstrap (Geoffrey Chew), temuan Wilhelm Roentgen mengenai sinar X, efek uranium terhadap piringan-piringan foto yang tertutup (Hendri Besqueral), polonium dan radium (Pierre dan Marie Curie), dissipative structure (sistem tapal batas hidup-mati; Ilya Prigogine), biologi molekuler, genetika, neuroscience, hingga teori chaos yang dikaitkan dengan sistem-sistem yang kompleks, acak, tak teramal, samar (fuzzy), dan paradoks. Semua itu menjelaskan ketidak-

${ }^{12}$ Helge Kragh, Quantum Generation: A History of Physics in the Twentieth Century, (New Jersey: Princeton University Press, 1999), h. 206. 
sederhanaan kosmos yang terkait dengan astrofisika dan fisika nuklir modern dengan menggunakan perangkat penjabaran matematika tingkat tinggi yang rumit. Hal ini belum dikaitkan dengan perspektif sosial, antropologi, ekonomi, dan seluruh gugusan pengertian manusia mengenai fenomen semesta raya yang hidup secara holistik. Semua itu merupakan temuan-temuan yang mengejutkan, setelah sebelumnya atom dianggap sebagai tidak dapat dibagi dan tidak dapat rusak.

Unsur yang paling menonjol dari pandangan-pandangan kosmologi baru itu adalah bahwa betapapun kecilnya perubahan dalam unsur-unsur tetap fisik tertentu (physical constants), akan ber-akibat pada semesta raya yang tidak dapat dihuni lagi. Perlu dipahami bahwa semesta raya yang kita diami ini adalah salah satu dari beberapa semesta yang memiliki parameter yang bersifat tepat dan sesuai bagi eksistensi segala sesuatu yang menyerupai kehidupan organis. Oleh sebabitu, kemungkinan bagi berlangsungnya kehidupan adalah sangat tergantung pada konsistensi parameter-parameter yang mendasari itu, yang mana konsistensi itu sendiri bersifat kemungkinan-kemungkinan yang sangat peka terhadapnya. ${ }^{13}$ Persis ungkapan di awal makalah ini, seluruh isi semesta raya termasuk manusia berada dalam kelangsungan konsistensi tersebut.

Kalangan agamawan menyebut kecenderungan di atas sebagai bentukpenciptaan dan penjagaanyang tiadahentidariTuhan.Namun, para kosmolog kontemporer menyebutnya sebagai proses organis yang saling terkait antara unsur-unsur yang membentuk keseluruhan wujud, dan bukan hanya sekedar penjumlahan dari unsur-unsur dan bagian-bagiannya. Keseluruhan wujud (realitas) berproses, dan unsur-unsurnya saling terkait. Setiap unsur dari keseluruhan sistem menyumbang pada kegiatan seluruh sistem sebagai satu kesatuan, dan sebaliknya, keseluruhan sistem mempengaruhi kegiatan masingmasing unsur atau bagiannya. ${ }^{14}$ Dengan kata lain, berbeda dengan warisan Cartesian-Newtonian yang mekanistik, proses kosmos ini dipandang sebagai sesuatu yang senantiasa bergerak secara dinamis, berubah, dan mengandung unsur baru. Bahkan, kedinamisan ini

${ }^{13}$ John Barrow \& Frank Tipler, The Anthropic Cosmological Principle, (New York: Oxford University Press, 1986), h. 154.

${ }^{14}$ Whitehead, Science and the Modern World, (New York: The Free Press, 1967), h. 80, 107. 
tidak hanya terjadi pada kosmos, tetapi juga tentang manusia dan Tuhan.

Beberapa penelitian mutakhir tentang energi dan materi yang terkait dengan bagian-bagian terkecil dari semesta raya ini, justu memperkuat asumsi-asumsi kosmologi baru ini. Beberapa yang dapat disebutkan di sini di antaranya: pertama, seluruh bendabenda selalu mengalami perubahan dan senantiasa berproses, seperti membesar, rusak, layu dan seterusnya. Kedua, benda-benda fisik selalu mengalami atau dipengaruhi oleh transformasi internal dalam beragam tingkatan. Ketiga, "materi" menjadi semakin asing untuk diidentifikasi. Meskipun kita dapat mengadakan kontak atau mengadakan eksperimen terhadap benda-benda fisik dengan panca indera kita, namun kita tidak dapat merasakan apakah hakikat materi itu. "Materi" menjadi istilah yang abstrak bagi konsep yang dipakai untuk segala perasaan (sensation) yang disebabkan oleh benda-benda itu.

Sebagian kecil ahli pikir, yaitu kelompok materialis, berpendapat bahwa materi adalah yang wujud dan pokok. Sementara itu, kalangan besar ahli pikir mengingkari bahwa materi adalah yang wujud yang pertama, tapi sebaliknya, mereka mengatakan bahwa jiwa (mind, spirit) atau sesuatu yang bukan materi adalah yang terpenting. Kebanyakan ahli sains dan filosof tidak berpegang kepada pendirian yang ekstrim. ${ }^{15}$ Mereka tidak lagi berani menjawab pernyataanpernyataan yang abstrak ini secara tuntas. Meskipun setiap menit kita menulis atau berpidato tentang kesejahteraan yang rohani dan yang jasmani, benda mati, benda hidup, dan sebagainya, namun apa itu jasmani, rohani, dan materi tetap tersembunyi. Apakah atom dari benda mati $\mathrm{H}_{2} \mathrm{O}$ itu sungguh mati? Sementara sebelumnya, kita dididik untuk "percaya" bahwa sains modern mampu menerangkan dan dapat dipercaya objektivitasnya. Pembongkaran ulang kosmolog kontemporer inilah yang berimplikasi langsung pada diakuinya bentuk pluralitas realitas dan relativitas kebenaran. Individualitas dan integritas tiap peristiwa dipertahankan dalam perpaduan organis dengan peristiwa-peristiwa yang lain. Demikian pula, gerak dan sudut pandang subjek diakui secara lebih penting daripada

${ }^{15}$ Harold H. Titus, dkk., Persoalan-Persoalan Filsafat, terj. H.M. Rasjidi, (Jakarta: Bulan Bintang, 1984), h. 274. 
dahulu. Tepatnya, tak ada satu gerak yang pasti dan sebenarnya (frame of reference) jika kita memikirkan tentang kejadian alam. Semuanya bergantung dari ruang dan waktu yang mengitari sudut pandang tersebut. ${ }^{16}$

Sementara itu, sains dan kosmologi kontemporer telah mulai pula menemukan keterbatasan-keterbatasannya, walaupun upaya pengembangan masih senantiasa digalakkan. Mengaca dari keterbatasan itu, para ilmuwan mengajukan beberapa prinsip tentangnya: ${ }^{17}$

1. Penyelidikan ilmiah hanya akan memperoleh hasil sejauh yang ditemukan oleh metode dan instrumen penelitian.

2. Klasifikasi ilmiah memang mampu memberikan beragam informasi yang berguna, akan tetapi tak ada klasifikasi yang menurut segala sesuatu yang terdapat dalam subyek yang diklasifikasikan.

3. Keseluruhan (totalitas) bisa jadi memiliki sifat yang tak terdapat pada bagian-bagiannya.

4. Terkait dengan relativitas interpretasi dan kebenaran, bisa jadi terdapat beberapa interpretasi tentang suatu benda, seseorang atau suatu kejadian; di mana masing-masing interpretasi itu adalah benar sepanjang batas-batasnya. Tiap interpretasi dapat memberi penjelasan dari salah satu segi pandangan. Umpamanya, seorang tani yang sangat gusar ketika melihat anak-anak mencuri apelnya. Beberapa interpretasi dari fenomena itu bisa menemukan ketidaksamaan. Seorang psikolog menjelaskan keadaan itu dan mengatakan: "Suatu perangsang telah menimbulkan respons". Seorang fisiolog melukiskannya sebagai suatu gerak jantung yang bertambah cepat dan oksidasi yang bertambah. Seorang dokter menjelaskannya sebagai kecepatan yang bertambah dari molekul yang ada dalam darah. Sedangkan seorang yang berdiri dekat dengannya hanya berkata: "Petani itu marah". Kita tidak layak untuk mengklaim interpretasi mana yang paling benar, karena masing-masing menjelaskan kejadian menurut segi pandangan pribadinya. Implikasi langsung dari hal ini, mungkin ada orang yang menafsirkan

${ }^{16}$ Ibid., h. 277.

${ }^{17}$ Ibid., h. 267-272. 
sejarah hanya atas dasar perubahan iklim, kekuatan-kekuatan ekonomi, bahkan atas faktor biologis. Perilaku manusia telah dijelaskan atas dasar kondisi kelenjar, dorongan-dorongan psikologis dan desakan-desakan lingkungan. Walaupun faktor-faktor tersebut adalah penting, akan tetapi kita harus curiga terhadap usaha untuk menjelaskan kejadian-kejadian yang kompleks dengan menggunakan hanya seperangkat konsep-konsep.

5. Jika kita mengamati sesuatu yang sedang dalam proses perkembangan, kita akan menemukan bahwa tahap yang terakhir sama riil benarnya dengan tahap-tahap yang sebelumnya, dan malah mungkin lebih informatif tentang watak proses tersebut.

6. Sains bergantung pada indera manusia dan peralatan intelektual umumnya.

\section{Kosmologi Baru: Tantangan Bagi Agama-agama}

Bagaimanakah jika suatu saat perkembangan sains dalam kosmologi baru ini sampai pada kesimpulan bahwa sesungguhnya semesta raya ini tidak punya awal dan akhir? Bagaimanakah jika suatu saat manusia bisa menunda kebusukan dengan memanfaatkan lemari es, sehingga proses pembusukan (baca: kematian) bisa ditunda sekehendak manusia? Bagaimanakah jika perkembangan sains mampu menembus kecepatan cahaya, sehingga bisa mempersempit atau memelarkan waktu?

Menilik perkembangan sains dan teknologi dewasa ini, kita bisa memunculkan banyak pertanyaan, baik yang berbentuk spekulatif, khayalan, fantasi, ataupun yang benar-benar serius, sehingga tidak boleh diabaikan. Akan tetapi, kemajuan sains dan teknologi sendiri justru menyiratkan bahwa tiada yang sungguhsungguh fantasi, khayalan dan imajinasi. Zaman dulu orang mungkin dianggap berkhayal jika mengangankan "capung besar" yang terbang di udara. Akan tetapi saat ini, helikopter dan bahkan pesawat jet berkecepatan tinggi sudah tidak asing lagi kita temukan. Bukankah suatu temuan awalnya juga diawali dengan imajinasiimajinasi spekulatif ini? Yang bisa dipastikan dari perkembangan itu, sebagaimana kerangka yang penulis gunakan dalam makalah ini - jika sains dan teknologi memunculkan pergeseran paradigmatik 
dikarenakan munculnya cara pandang kosmologi baru dewasa ini, maka tentunya, peradaban manusia juga mengalami pergeseranpergeseran di sana-sini. Setidaknya, manusia - intelektual atau anti intelektual; agamawan atau tidak - tentu akan terkena dampak dari pergeseran cara pandang kosmologi dan paradigma ini.

Justru pada agama pergesekan ini akan nampak jelas, karena agama memiliki unsur yang sama untuk menopang ajaran-ajarannya; yakni kosmologi. Peralihan paradigma dan cara pandang keagamaan dipengaruhi oleh sistem referensial tertentu yang menjadi bahan dasar pembentuknya. Dan pada gilirannya, paradigma itu berimplikasi langsung pada corak peradaban yang dihasilkan agama tersebut. Di sini, bisa dipastikan bahwa semua bentuk kepercayaan dan agama, baik yang meyakini adanya wahyu ilahiyyah atau tidak, berpijak pada suatu kosmologi tertentu. Kosmologi itu mengajarkan bahwa semesta raya ini diciptakan oleh Tuhan, tidak abadi, punya awal dan akhir, selalu dalam pengawasan-Nya, dan seterusnya. Perkembangan paham kosmologi agama-agama mengenalkan istilah-istilah ruang, waktu, materi, aksidensi, dan sebagainya. Semua itu diterima dari ajaran-ajaran agama secara taken for granted, dan tidak perlu dikaji lebih lanjut. Terhadap ajaran agama ini, kalangan agamawan mengandalkan iman yang tidak boleh diganggu-gugat.

Mengambil langkah yang ekstrim untuk memisahkan dua hal ini (agama dan sains) bukanlah keputusan yang bijak. Ketegangan yang terjadi antara keduanya memang tidak bisa - dan bahkan tidak perlu - dihindari. Dalam Islam saja, umpamanya, ketegangan antara sains (yang berbasis pada pandangan filsafat) dengan agama (yang mengakar pada pandangan teologi) sudah ditemukan sejak dini. Para pendukung teologi telah menepikan studi filsafat (sains) begitu saja. Sebutlah - sebagai contoh - polemik antara al-Gazāli (1058-1111) dan Ibn Sinā (980-1037), yang masih mencekam hingga saat ini. Padahal, perkembangan filsafat setelah itu, telah menghasilkan terobosanteobosan sains yang tidak sedikit. Fazlur Rahman sampai-sampai mengungkapkannya sebagai bunuh diri intelektual (intellectual suicide), ${ }^{18}$ dikarenakan pilihan dikotomis yang memojokkan dan memaksa untuk memilih salah satunya: agama atau sains.

${ }^{18}$ Fazlur Rahman, Islam \& Modernity: Transformation of an Intellectual Tradition, (Chicago: The University Press, 1982), h. 158. 
Respon yang lain menunjukkan bahwa para saintis dan teolog mencoba menghubungkan sains dan agama secara langsung sehingga terasa kurang matang dan tidak mendalam. Hal ini karena kedua-duanya sama-sama melupakan sumbangan filsafat dalam membuat klarifikasi tentang duduk perkara persoalan yang sedang diperbincangkan. Di samping ada juga para filosof yang tidak memiliki hubungan erat dengan kalangan agamawan dan saintis, sehingga rumusan sumbangan pemikiran mereka yang abstrak hanya bersinggungan secara minim sekali dengan apa yang sebenarnya dikembangkan oleh para teolog dan saintis itu. ${ }^{19}$ Dengan demikian, masih dituntut upaya yang lebih sistematis untuk memformat ulang relasi yang tepat antara kutub-kutub yang saling berseberangan ini. Sebab, jika disikapi secara reaktif, tantangan kosmologi baru ini bagi kalangan agamawan hanya akan berakibat negatif yang tidak sedikit.

\section{E. Penutup}

Sebagai catatan akhir tulisan ini, agaknya perkembangan kosmologi belakangan ini membawa dampak serius bagi sains dan agama. Dalam hal ini hubungan keduanya harus mempersiapkan paradigma berpikirnya masing-masing. Terlebih agama yang sejauh ini diketahui berbasis pada pandangan-pandangan kosmologis. Perkembangan pandangan kosmologi yang terjadi dewasa ini juga semestinya tidak lagi menempatkan sains dan agama pada posisi yang saling berhadap-hadapan. Keduanya mampu berjalan seiring sebagaimana yang usulkan oleh filosof muslim awal seperti Ibnu Rusyd. Namun dalam hal ini sains dan agama itu diperlukan filsafat sebagai katalisator dalam menyusun langkah keduanya. []

\section{Daftar Pustaka}

Bagus, Lorens, Kamus Filsafat, Jakarta: Gramedia, 2000.

Barbour, Ian G., Issues in Sciences and Religion, New York: Harper Torchbooks, 1966.

${ }^{19}$ Ian G. Barbour, Issues in Sciences and Religion, (New York: Harper Torchbooks, 1966), h. 11. 
Barrow, John \& Tipler, Frank, The Anthropic Cosmological Principle, New York: Oxford University Press, 1986.

Descartes, Rene, Discourse on Mehtod, trans. John Veitch, London: J.M. Dent \& Sons Ltd., 1960.

Habermas, Jurgen, Knowledge and Human Interest, Boston: Beacon Press, 1972.

Hamlyn, D.W., The Penguin History of Western Philosophy, London: Penguin Books, 1987.

Hadi, Protasius Hardono, Epistemologi: Filsafat Pengetahuan, Yogyakarta: Kanisius, 1994.

Heisenberg, W., Physics and Philosophy, New York: Harper \& Row, 1958.

Kuhn, Thomas S., The Structure of Scientific Revolution, Chicago: The University of Chicago Press, 1970.

Kragh, Helge, Quantum Generation: A History of Physics in the Twentieth Century, New Jersey: Princeton University Press, 1999.

Mautner, T., (ed.), Dictionary of Philosophy, London: Penguin Books, 1996.

Microsoft.Co., Microsoft Encarta Reference Library Premium \& Encyclopedia Deluxe 2005.

Nasr, Seyyed Hossein, Religion and the Order of Nature, Oxford: Oxford University Press, 1996.

Rahman, Fazlur, Islam \& Modernity: Transformation of an Intellectual Tradition, Chicago: The University Press, 1982.

Smith, Huston, Forgotten Truth: The Common Vision of the World's Religions, New York: HarperCollins, 1992.

Titus, Harold H., (dkk.). Persoalan-Persoalan Filsafat, terj. H.M. Rasjidi, Jakarta: Bulan Bintang, 1984.

Whitehead, Science and the Modern World, New York: The Free Press, 1967. 